\title{
Penanggulangan depresi anak pascaerupsi Gunung Merapi melalui pelatihan permainan berbasis kearifan budaya lokal pada guru dan orang tua murid taman kanak-kanak
}

\author{
Sumarni, ${ }^{1, *}$ Cecep Sugeng Kristanto, ${ }^{1}$ Andrian Fajar Kusumadewi, ${ }^{1}$ Santi Yuliani, ${ }^{2}$ \\ Nanda Kusumaningrum ${ }^{3}$ \\ ${ }^{1}$ Departemen Psikiatri, Fakultas Kedokteran, Kesehatan Masyarakat, dan Keperawatan, \\ Universitas Gadjah Mada, Yogyakarta, Indonesia \\ ${ }^{2}$ Rumah Sakit Jiwa Prof. Dr. Soerojo Magelang, Magelang, Indonesia \\ ${ }^{3}$ Mahasiswa Program Ners Ilmu Keperawatan, Fakultas Kedokteran, Kesehatan Masyarakat, dan \\ Keperawatan, Universitas Gadjah Mada, Yogyakarta, Indonesia
}

\section{Submitted: 17 Oktober 2018 Revised: 10 Januari 2019 Accepted: 12 Januari 2019}

\begin{abstract}
ABSTRAK Kesehatan mental anak menjadi prioritas utama Program Nasional Anak Bagi Indonesia (PNBAI) tahun 2015 dengan visi anak Indonesia sehat, tumbuh dan berkembang, serta terlindungi dan berpartisipasi secara aktif. Erupsi Gunung Merapi memiliki dampak besar pada kehidupan masyarakat yang menyebabkan warga kehilangan pekerjaan. Sebagian orang tua kemudian menjadi penambang pasir dari pagi sampai larut malam. Ibu menjadi jarang memperhatikan anak. Kejadian traumatik dan penerapan pola asuh yang salah meningkatkan kecenderungan depresi. Depresi pada anak merupakan masalah kesehatan yang penting. Ketidaktahuan orang tua dan guru akan berdampak pada keterlambatan deteksi dan pengobatan depresi pada anak yang berdampak buruk terhadap prestasi dan masa depan anak. Pada pengabdian kepada masyarakat sekaligus penelitian ini, dilakukan pelatihan terhadap 12 guru, 55 orang tua murid, dan 55 murid Taman Kanak-Kanak (TK) Kuncup Mekar dan TK Aisyiyah Bustanul Athfal (ABA), Cangkringan, Sleman. Alat yang digunakan dalam pelatihan adalah modul deteksi dini depresi anak, modul permainan berbasis kearifan budaya lokal, peralatan permainan, dan Child Depression Inventory (CDI). Keberhasilan pelatihan dievaluasi menggunakan perubahan nilai pre-test dan post-test, serta wawancara. Kecenderungan depresi pada anak sebelum dan sesudah pelatihan dinilai menggunakan CDI. Setelah pelatihan, nilai rata-rata tingkat pengetahuan tentang deteksi dini dan penanggulangan depresi pada anak meningkat dari 33,7 menjadi 68,0 , sedangkan nilai rata-rata tingkat ketrampilan memainkan permainan berbasis kearifan budaya lokal meningkat dari 43,9 menjadi 85,2. Murid yang mengalami kecenderungan depresi menurun dari 37 anak (67\%) menjadi 16 (39\%). Pelatihan permainan berbasis kearifan budaya lokal dapat meningkatkan pengetahuan dan ketrampilan guru dan orang tua murid TK dalam menanggulangi depresi pada anak pascaerupsi Gunung Merapi.
\end{abstract}

KATA KUNCI depresi pada anak; permainan berbasis kearifan budaya lokal; murid TK, pola asuh; program psikososial

ABSTRACT Child mental health is a top priority of the National Program for Indonesian Children 2015 with the vision of enabling Indonesian children to grow and develop in good health, to be protected and to actively participate. The Mount Merapi eruption had a major impact on the lives of the people living nearby. Many livelihoods came to a halt, forcing some people to work as sand miners from early morning until late at night. As a result, children receive less time and attention from their mothers. The combination of 
traumatic events and unsuitable parenting increase the tendency for depression, a grave health problem in children. Lack of awareness among parents and teachers can cause a delay in the detection and treatment of depression in children, which will negatively affect the children's school performance and future. This community service and research project held a training on childhood depression. Twelve teachers, 55 parents, and 55 students of Kuncup Mekar Kindergarten and Aisyiyah Bustanul Athfal (ABA) Kindergarten, Cangkringan, Sleman participated in the training. The training tools included module of early detection for childhood depression, module of game based on local wisdom, game equipment, and the Child Depression Inventory (CDI). The output of the training was evaluated by comparing pre-test and post-test results, as well as interviews. The tendency of depression in the participating children before and after training was assessed using CDI. After the training, the average level of knowledge on early detection and prevention of depression in children increased from 33.7 to 68.0, while the average skill level in playing traditional games increased from 43.9 to 85.2. The number of students with depression tendencies declined from 37 children (67\%) to 16 (39\%). Traditional game training can increase the knowledge and skills of teachers and parents of kindergarten students in tackling depression in children after the eruption of Mount Merapi.

KEYWORDS childhood depression; traditional games; kindergarten students; parenting; psychosocial program

\section{Pendahuluan}

Program Nasional Bagi Anak Indonesia (PNBAI) 2015 mempunyai visi yaitu anak Indonesia yang sehat, tumbuh dan berkembang, terlindung dan aktif berpartisipasi. PNBAI berfokus pada 4 program pokok, yaitu bidang kesehatan, bidang pendidikan, bidang perlindungan anak, dan bidang penanggulangan human immunodeficiency virus/ acquired immunedeficiency syndrome (HIV/ AIDS). ${ }^{1}$ Warga hunian tetap (huntap) di Kecamatan Cangkringan, Sleman, mengalami peristiwa yang lebih traumatis dibandingkan warga huntap yang lainnya akibat erupsi Gunung Merapi pada tanggal 25 Oktober sampai 30 November 2010 yang sangat dahsyat. ${ }^{2}$ Selain erupsi Gunung Merapi, warga huntap Kuwang dan Gondang sering terpapar banjir lahar dingin dari Sungai Gendol yang sering memakan korban jiwa. Korban jiwa yang meninggal dari Kecamatan Cangkringan paling banyak (103 orang), sedangkan yang mengalami cidera 35 orang. Di antara korban yang mengalami cidera, banyak yang mengalami kecacatan fisik permanen karena terlambat dievakuasi.

Anak-anak merupakan kelompok yang sangat rentan terkena dampak bencana alam. Anak-anak yang terpapar bencana lebih berisiko mengalami gangguan mental dibandingkan dengan anak yang tidak terpapar bencana. ${ }^{3}$ Gangguan stres pascatrauma pengaruhnya lebih buruk pada anak-anak. Sebanyak 40\% anak-anak mengalami gangguan stres pascatrauma setelah kejadian bencana alam. Pada penelitian awal terhadap 1.985 anak berusia 4-18 tahun yang merupakan penyintas gempa bumi dan tsunami di Kabupaten Aceh Utara, Provinsi Nanggroe Aceh Darusalam (NAD), didapatkan 9,62\% anak mengalami gangguan jiwa dan $60,5 \%$ didiagnosis mengalami gangguan stres pascatrauma. ${ }^{4}$ Pascagempa bumi di Daerah Istimewa Yogyakarta (DIY), dijumpai $12,5 \%$ anak mengalami depresi ringan, $47 \%$ mengalami depresi sedang, dan $40,5 \%$ mengalami depresi berat sehingga membutuhkan pertolongan psikolog dan psikiater pada anak usia taman kanakkanak (TK) di Kabupaten Sleman. ${ }^{5}$ Berdasarkan hasil wawancara mendalam dengan guru TK diperoleh keterangan bahwa terdapat perubahan perilaku pada murid-murid setelah gempa bumi, antara lain menjadi penakut, cengeng, tambah nakal, menjadi agresif, gelisah, dan tidak dapat berkonsentrasi. ${ }^{5}$ Kejadian traumatis tersebut sering mengakibatkan perubahan dalam kehidupan anak, dan mempengaruhi perkembangan kemampuan fungsi kognisi, reaksi emosi, dan kemampuan mereka dalam bersosialisasi. Sebagian besar ibu di hunian sementara (huntara) di Kecamatan Cangkringan, Sleman, mengeluhkan bahwa anak-anak mereka yang berusia di bawah lima tahun (balita) sering 
rewel, tambah nakal, penakut, sering terbangun menangis di malam hari, dan sering sakit-sakitan. ${ }^{5}$ Guru-guru TK di Kecamatan Cangkringan juga menyatakan bahwa muridnya menjadi penakut, cengeng, nakal, agresif, dan susah berkonsentrasi dalam belajar.

Selain korban jiwa meningggal dan cidera, peristiwa erupsi Gunung Merapi juga menyebabkan warga kehilangan pekerjaan sehingga sebagian orang tua, khususnya ibu beralih kerja dengan menjadi penambang pasir di Sungai Gendol. Mereka berkerja dari pagi hingga larut malam. Pekerjaan tersebut memiliki risiko kecelakaan yang tinggi. Pekerja berisiko meninggal dunia karena terjangan banjir lahar dingin dan tanah longsor saat sedang mengangkut pasir. Kesibukan orang tua untuk mencari nafkah tersebut sangat memengaruhi pola pengasuhan anak. Anak-anak menjadi sering ditinggal bersama kakaknya di rumah. Sebagian orang tua terpaksa membawa anaknya saat bekerja di Sungai Gendol. Anak mereka biasanya dibiarkan bermain dan ditidurkan di tepi Sungai Gendol sehingga keselamatan anak turut terancam. Selain itu, kondisi tersebut meningkatkan risiko kecenderungan depresi pada anak.

Gangguan depresi pada anak merupakan masalah kesehatan yang penting untuk diperhatikan dengan serius. Ketidaktahuan orang tua dan guru terhadap hal tersebut akan menyebabkan keterlambatan penanganan, memperburuk kondisi, menurunkan prestasi sekolah, dan mengganggu pergaulan di lingkungan sekolah. Depresi pada anak dapat berupa iritabilitas yang bermakna, agresifitas, penurunan prestasi, perilaku melawan atau menentang, serta temper tantrum. Anak dengan depresi sering mengeluhkan gangguan fisik, pikiran-pikiran, mimpi-mimpi, cerita-cerita, atau gambar-gambar yang bertemakan kesedihan. Gejala-gejala tersebut merupakan respon terhadap stressor yang dialami oleh anak. ${ }^{6,7,8}$

Bencana alam memberikan efek jangka panjang pada sekitar 40\% sampai $68 \%$ korban dan dapat bertahan selama 33 tahun dalam kehidupannya. ${ }^{9}$ Permasalahan gangguan kejiwaan pada anak pascabencana merupakan masalah yang mendesak untuk diperhatikan dan ditangani dengan efektif dan berkesinambungan karena perkembangan jiwa anak dan balita merupakan dasar bagi perkembangan jiwa di masa remaja dan dewasa. Salah satu upaya untuk menanggulangi kecenderungan depresi pada anak pascerupsi Gunung Merapi adalah dengan memberikan pelatihan deteksi dini kecenderungan depresi anak serta penanggulangannya dan pelatihan permainan berbasis kearifan budaya lokal pada guru dan orang tua murid TK. Guru dan orang tua murid TK diharapkan dapat mengaplikasikan pengetahuan yang diperoleh terhadap anak didik atau anak mereka.

Penelitian ini bertujuan untuk mengevaluasi peningkatan pengetahuan mengenai deteksi dini kecenderungan depresi pada anak dan penanggulangannya serta peningkatan keterampilan penanggulangan depresi anak dengan permainan berbasis kearifan budaya lokal pada guru dan orang tua murid TK di Huntap Gondang dan Kuwang, Kecamatan Cangkringan, Kabupaten Sleman. Selain itu, derajat depresi anak juga dievaluasi dengan membandingkan derajat depresi antara sebelum dan sesudah pelatihan pada guru dan orang tua murid TK.

\section{Metode}

Data yang digunakan dalam penelitian ini diambil dari laporan pengabdian kepada masyarakat berupa pelatihan yang dilakukan pada Juni - Agustus 2013 di Huntap Gondang dan Kuwang, Kecamatan Cangkringan, Kabupaten Sleman. Subjek penelitian terdiri dari 12 orang guru TK, 55 orang tua murid, dan 55 murid TK Kuncup Mekar dan TK Aisyiyah Bustanul Athfal (ABA), Cangkringan, Sleman. Media pelatihan yang digunakan adalah modul deteksi dini depresi anak, modul permainan berbasis kearifan budaya lokal, peralatatan permainan, dan Child Depression Inventory (CDI). Data yang dianalisis meliputi karakterisrik responden (guru TK: pendidikan; ibu: umur, pendidikan, dan pekerjaan; murid TK: jenis kelamin dan urutan kelahiran anak), kecenderungan depresi murid TK sebelum dan sesudah pelatihan, tingkat pengetahuan guru dan orang tua murid TK mengenai deteksi dini kecenderungan depresi pada anak dan cara penanggulangannya sebelum dan sesudah pelatihan, serta tingkat keterampilan 
memainkan permainan berbasis kearifan budaya lokal pada guru dan orang tua murid TK sebelum dan sesudah pelatihan. Kecenderungan depresi pada anak dinilai menggunakan CDI. Selain itu, dilakukan juga wawancara dengan guru dan orang tua murid, serta observasi secara langsung. Data disajikan secara deskriptif, baik kuantitatif maupun kualitatif.

Pelatihan deteksi dini kecenderungan depresi dan penanggulangannya dengan dukungan sosial kepada guru dan orang tua murid TK dilaksanakan berdasarkan modul pengetahuan deteksi dini kecenderungan depresi pada anak TK. Pelatihan dilakukan sebanyak dua kali dalam seminggu, di masing-masing TK. Materi pelatihan meliputi pengertian depresi pada anak, gejala-gejala yang khas pada anak [keluhan fisik, gangguan makan, gangguan tidur (mimpi buruk), agresif, temper tantrum, menentang, cengeng, dan penurunan prestasi], dan penggunaan alat deteksi dini $\mathrm{CDI} .{ }^{10}$ Selain itu, dilakukan juga pelatihan dukungan sosial kepada guru dan orang tua murid TK.

Pelatihan penanggulangan depresi dengan permainan berbasis kearifan budaya lokal Sleman kepada guru dan orang tua murid TK dilaksanakan satu kali dalam seminggu selama dua bulan di masing-masing TK, berdasarkan modul permainan berbasis kearifan budaya lokal Sleman. Permainan yang digunakan terdiri dari 4 paket, yaitu paket permainan I (jamuran, engklek, lagu "Padhang Mbulan", dan lagu "Suwe Ora Jamu"), paket permainan II (cublak-cublak suweng, kucingkucingan, lagu "Gambang Suling", dan lagu "SlukuSluku Bathok"), paket permainan III (jaranan, endhog-endhogan, lagu "Lir-ilir", dan lagu "GundulGundul Pacul"), dan paket permainan IV (dingklik oglak-aglik, dakon, bekelan, lagu "Menthokmenthok", dan lagu "Kidang Talun").

Pelatih terdiri dari satu orang psikiater, satu orang sosiolog, satu orang dokter, dan lima orang mahasiswa keperawatan yang sudah dilatih untuk membantu melakukan permainan, menyanyikan lagu dolanan, dan menari berbasis kearifan budaya lokal Sleman. Sebelum dan sesudah pelatihan, dilakukan pengukuran tingkat pengetahuan dan keterampilan.

\section{Hasil}

Subjek penelitian ini terdiri dari dan 12 orang guru, 55 orang tua murid, dan 55 murid dari dua TK kelas B di Huntap Gondang dan Kuwang, Kecamatan Cangkringan, Sleman. Karakteristik subjek disajikan pada Tabel 1.

Tabel 1 menunjukkan bahwa sebagian besar (52\%) orang tua murid berusia antara 30-40 tahun, dengan status pendidikan terakhir umumnya SMP (50\%), dan sebagian besar merupakan ibu rumah tangga (53\%). Murid didominasi murid berjenis kelamin perempuan (56\%) dan sebagian besar adalah anak kedua (56\%). Sebagian besar guru TK (75\%) sudah mengenyam pendidikan setara D3 dan S1. Observasi yang dilakukan oleh tim menunjukkan bahwa terdapat beberapa anak yang mengalami kecenderungan depresi. Kecenderungan depresi yang dialami anak dapat diwujudkan sebagai takut, suka menyendiri, dan cengeng (Gambar 1 ).

Pemberian pelatihan meningkatkan pengetahuan guru dan orang tua murid TK di Huntap Gondang dan Kuwang, Cangkringan, Sleman dalam bidang deteksi dini kecenderungan depresi pada anak dan cara penanggulangannya (Tabel 2). Guru-guru TK menjadi paham bahwa perilaku murid yang sangat nakal, agresif, menyakiti teman, atau sebaliknya menjadi penyendiri, penakut, cengeng, tidak berani bersosialisasi, dan gelisah merupakan gejala kecenderungan depresi pada anak yang memerlukan penanganan segera dan tepat. Sebelumnya guru-guru TK cenderung kurang sabar menghadapi perilaku murid yang nakal atau penakut dengan melakukan tindakan mendisiplinkan dan memaksa, namun setelah menerima pelatihan mereka menjadi lebih sabar dan mengerti bagaimana menangani para murid yang mempunyai kecenderungan depresi tersebut. "Saya dekati mereka dengan kasih sayang, saya arahkan untuk saling mengasihi, saya berikan pujian atas kelebihan-kelebihan yang mereka miliki, saya bangkitkan rasa percaya diri mereka, dan saya alihkan pikirannya dari kenangan traumatis 
Tabel 1. Karakteristik guru, orang tua murid, dan murid TK di Huntap Gondang dan Kuwang, Kecamatan Cangkringan, Sleman

\begin{tabular}{|c|c|c|}
\hline Karaketeristik & Jumlah & Persentase (\%) \\
\hline \multicolumn{3}{|c|}{ Orang tua murid TK $(n=55)$} \\
\hline \multicolumn{3}{|l|}{ Umur } \\
\hline $20-30$ & 15 & 27 \\
\hline $30-40$ & 29 & 52 \\
\hline$>40$ & 11 & 21 \\
\hline \multicolumn{3}{|l|}{ Pendidikan } \\
\hline SD & 14 & 27 \\
\hline SMP & 28 & 50 \\
\hline SMA & 13 & 23 \\
\hline \multicolumn{3}{|l|}{ Pekerjaan } \\
\hline Ibu rumah tangga & 29 & 53 \\
\hline Petani & 15 & 27 \\
\hline Peternak & 3 & 5 \\
\hline Karyawan & 8 & 15 \\
\hline \multicolumn{3}{|l|}{ Murid TK $(n=55)$} \\
\hline \multicolumn{3}{|l|}{ Jenis kelamin } \\
\hline Laki-laki & 24 & 44 \\
\hline Perempuan & 31 & 56 \\
\hline \multicolumn{3}{|l|}{ Anak ke- } \\
\hline 1 & 20 & 36 \\
\hline 2 & 31 & 56 \\
\hline 3 & 4 & 7 \\
\hline \multicolumn{3}{|l|}{ Guru TK $(n=12)$} \\
\hline \multicolumn{3}{|l|}{ Pendidikan } \\
\hline SMK & 4 & 25 \\
\hline D3/S1 & 8 & 75 \\
\hline
\end{tabular}

TTK: taman kanak-kanak; SD: sekolah dasar; SMP: sekolah menengah pertama; SMA: sekolah menengah atas; SMK: sekolah menengah kejuruan; D3: diploma 3; S1: strata 1

Tabel 2. Tingkat pengetahuan guru dan orang tua murid TK mengenai deteksi dini kecenderungan depresi pada anak dan cara penanggulangannya sebelum dan sesudah pelatihan

\begin{tabular}{lccc}
\hline \multirow{2}{*}{$\begin{array}{l}\text { Pengetahuan mengenai deteksi dini kecenderungan } \\
\text { depresi pada anak dan penanggulangannya }\end{array}$} & \multicolumn{2}{c}{ Nilai rata-rata pengetahuan } \\
\cline { 2 - 4 } & $\begin{array}{c}\text { Sebelum } \\
\text { pelatihan }\end{array}$ & $\begin{array}{c}\text { Sesudah } \\
\text { pelatihan }\end{array}$ & Perubahan \\
\hline $\begin{array}{l}\text { Pengertian dan gejala-gejala kecenderungan depresi } \\
\text { pada anak }\end{array}$ & 33,6 & 68,4 & 34,8 \\
$\begin{array}{l}\text { Faktor-faktor yang mempengaruhi kecenderungan } \\
\text { depresi pada anak }\end{array}$ & 37,4 & 71,3 & 33,9 \\
$\begin{array}{l}\text { Penanggulangan kecenderungan depresi pada anak } \\
\text { Rata-rata }\end{array}$ & 30,2 & 64,2 & 34,0 \\
\hline
\end{tabular}



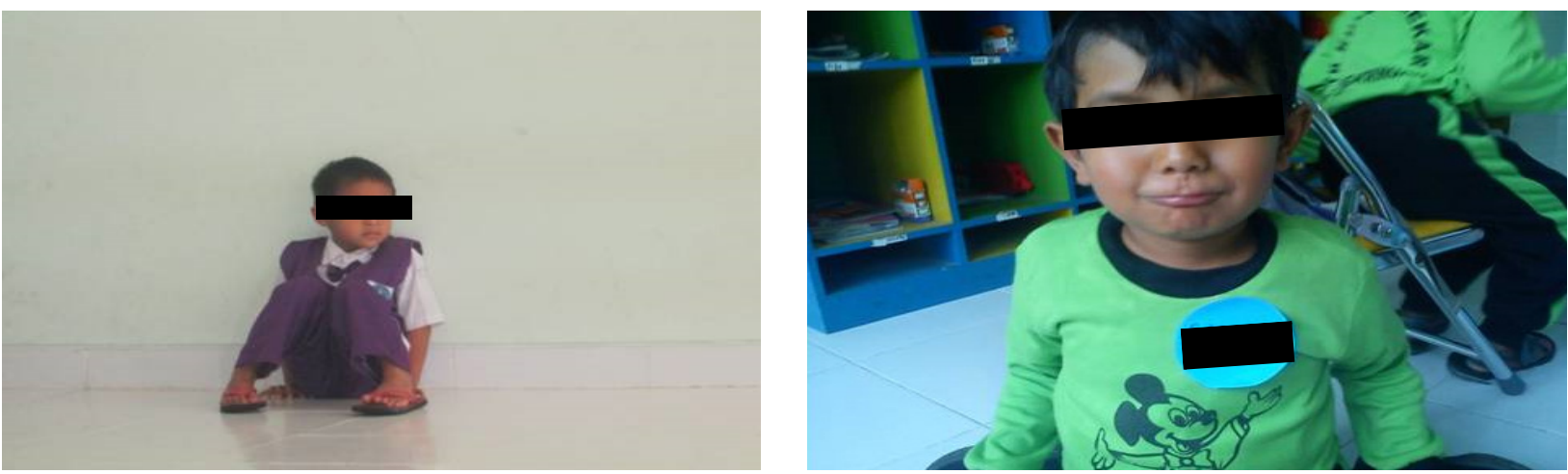

Gambar 1. Kondisi anak sebelum diintervensi dengan permainan berbasis kearifan budaya lokal. Anak tampak masih takut untuk tampil, cengeng, pendiam, dan suka menyendiri.

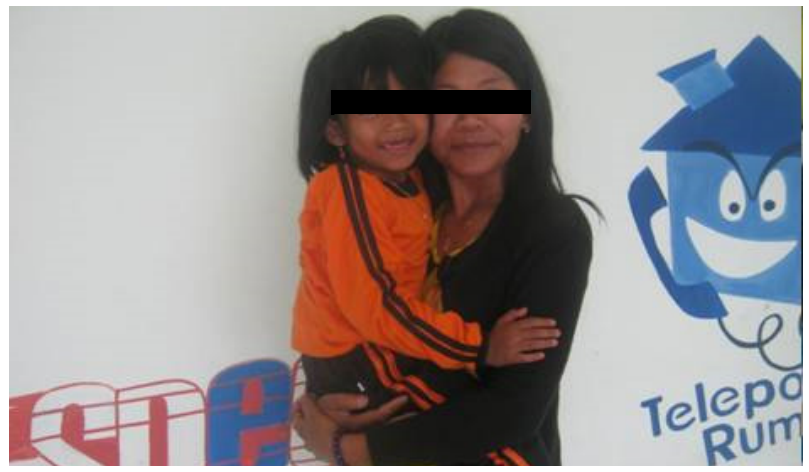

Gambar 2. Setelah pemberian pelatihan pengetahuan tentang deteksi dini kecenderungan depresi pada anak dan pelatihan ketrampilan permainan kearifan budaya lokal, orang tua murid dan guru menjadi lebih memahami anakanak dan lebih dekat, serta menghargai pentingnya meluangkan waktu bermain bersama.
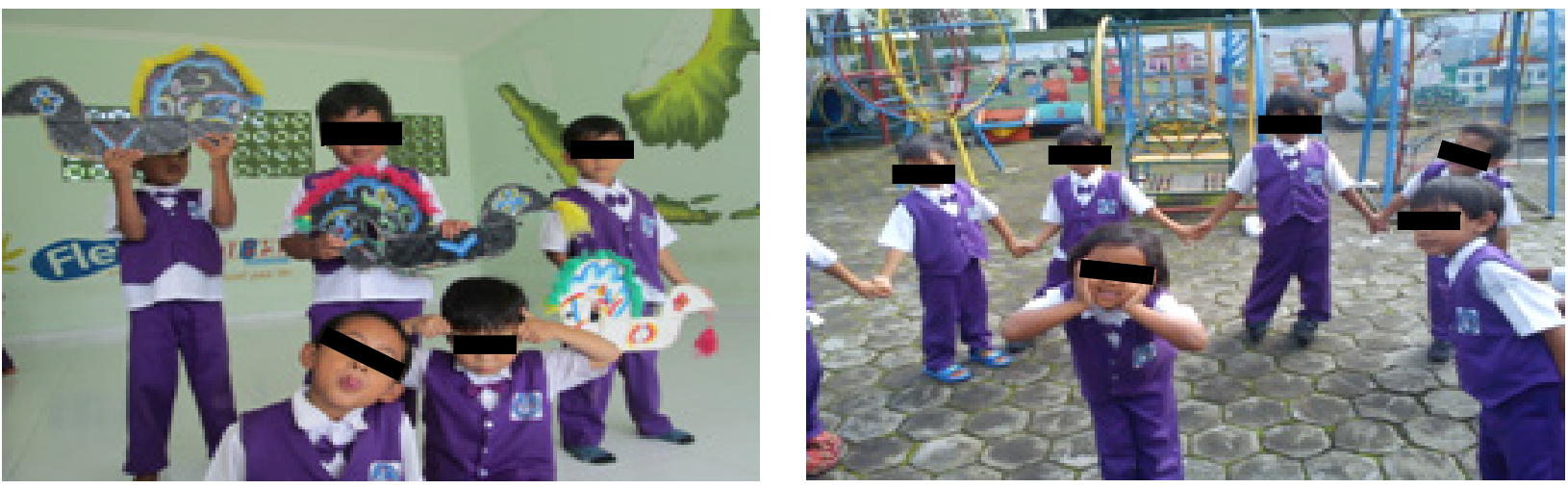

Gambar 3. Gambar-gambar perubahan perilaku anak setelah pelatihan. Anak menjadi senang, gembira, berani tampil, dan tidak cengeng lagi setelah pemberian perlakuan berupa permainan berbasis kearifan budaya lokal.

menjadi harapan yang cerah ke depan," kata salah seorang guru.

Demikian pula dengan orang tua murid TK. Sebelum pelatihan, mereka tidak mengetahui bahwa perilaku anak yang nakal, suka melawan, rewel, penakut, susah tidur, dan perilaku negatif lainnya merupakan gejala kecenderungan depresi. Mereka cenderung menanganinya secara represif. "Saya marahi", "Saya cubit", "Saya pukul", "Saya ancam", "Saya lempar pakai mainannya sampai nangis, karena saya sendiri sering stres, capai, 
jenuh, dan harus membantu mencari nafkah," kata beberapa ibu terkait tindakan mereka terhadap anak dengan kecenderungan depresi. Yang terjadi, anaknya justru semakin nakal dan melawan, rewel, tidak mau tidur, dan senang keluar rumah untuk bermain dengan temanteman yang usianya lebih tua. Setelah mengikuti pelatihan, para orang tua murid menjadi lebih mengerti bagaimana menangani anak-anak mereka yang berkecenderungan depresi dengan baik (Gambar 2). "Jika anak saya sering rewel, merasa ketakutan, dan tidak mau ditinggal bekerja, sekarang saya luangkan waktu untuk menunggui dulu, menemani bermain di rumah, dan tidak pernah saya cubit lagi". "Setelah mengikuti pelatihan, saya merasa lebih bisa memahami anak saya, kalau anak saya mulai nakal, agresif, melawan, saya segera beristighfar, saya peluk anak saya dengan lembut, saya tidak memukul dan melempar dengan mainannya lagi." "Saya suka menangis jika mengingat bagaimana kerasnya perlakuan saya kepada anak saya sebelum mengikuti pelatihan ini, saya tidak akan pernah melakukannya lagi, ia anak kecil yang butuh belaian dan kasih sayang ibu." Itulah kalimat-kalimat yang terlontar dari 3 orang ibu setelah mereka memahami bagaimana memperlakukan anak dengan kecenderungan depresi.

Pelatihan yang diberikan meningkatkan keterampilan guru dan orang tua murid TK dalam bermain permainan berbasis kearifan budaya lokal lengkap dengan lagu pengiringnya, serta menari dan menyanyikan lagu berbasis kearifan budaya lokal atau lagu permainan Jawa (Tabel 3). Selain menjadi lebih menguasai permainan, tarian, dan lagu berbasis kearifan budaya lokal, guru dan orang tua murid yang mengikuti pelatihan juga merasakan peningkatan rasa senang dan rasa percaya diri serta dapat tertawa lepas setiap selesai memainkan permainan dengan benar dan lucu. "Saya merasa sangat senang dan hilang stres saya, dan saya sangat menikmati permainan kearifan budaya lokal, dapat menghargai dan menyayangi murid, dan saya bisa bermain dengan murid-murid saya," kata salah seorang guru. Selaras dengan pernyataan guru tersebut,

Tabel 3. Nilai rata-rata keterampilan memainkan permainan berbasis kearifan budaya lokal para guru dan orang tua murid TK sebelum dan sesudah pelatihan

\begin{tabular}{lccc}
\hline \multicolumn{1}{c}{ Keterampilan } & \multicolumn{3}{c}{ Nilai rata-rata keterampilan } \\
\cline { 2 - 4 } & $\begin{array}{c}\text { Sebelum } \\
\text { pelatihan }\end{array}$ & $\begin{array}{c}\text { Sesudah } \\
\text { pelatihan }\end{array}$ & Perubahan \\
\hline $\begin{array}{l}\text { Memainkan permainan berbasis kearifan budaya lokal } \\
\text { dengan lagu pengiringnya }\end{array}$ & 40,4 & 84,1 & 43,7 \\
$\begin{array}{l}\text { Menari dan menyanyikan lagu berbasis kearifan } \\
\text { budaya lokal }\end{array}$ & 47,5 & 86,3 & 38,8 \\
Rata-rata & 43,9 & 85,2 & 41,3 \\
\hline
\end{tabular}

Tabel 4. Kecenderungan depresi pada murid TK Kuncup Mekar dan TK ABA Cangkringan sebelum dan sesudah pelatihan

\begin{tabular}{|c|c|c|c|}
\hline \multirow[b]{2}{*}{ Kecenderungan depresi } & \multicolumn{3}{|c|}{ Jumlah murid TK } \\
\hline & $\begin{array}{c}\text { Sebelum } \\
\text { pelatihan [n (\%)] }\end{array}$ & $\begin{array}{c}\text { Sesudah } \\
\text { pelatihan }[\mathrm{n}(\%)]\end{array}$ & Perubahan \\
\hline Ya & $37(67)$ & $16(39)$ & -21 \\
\hline Tidak & $18(33)$ & $39(71)$ & 21 \\
\hline
\end{tabular}


beberapa ibu menyatakan, "Saya benar-benar merasakan kegembiraan, stres dan kejenuhan saya hilang. Sekarang saya lebih menyayangi dan mengasihi dengan meluangkan waktu bermain bersama dengan anak, dan meningkatkan kasih sayang, serta dapat lebih menghargai melalui permainan. Selain itu, hubungan saya dengan anak menjadi lebih harmonis."

Sebelum pelatihan yang diadakan untuk guru dan orang tua murid, murid yang tidak mengalami kecenderungan depresi sebanyak 18 anak (32\%) dan yang mengalami kecenderungan depresi pascaerupsi Gunung Merapi sebanyak 37 anak (68\%) (Tabel 3). Tekanan psikososial yang berkepanjangan selama berada di pengungsian, bertahun-tahun tinggal di huntara yang sangat memprihatinkan, kemudian pindah ke lingkungan huntap menjadikan anak harus sering beradaptasi dengan lingkungan baru dan bergaul dengan anakanak yang lebih tua. Tekanan diperberat dengan tekanan yang muncul dari pola asuh ibu yang keras dan otoriter (memarahi anak jika bersikap tidak menurut, memukul, mencubit, bahkan melempar anak dengan mainannya, hingga mengancam) karena tekanan sosial ekonomi yang dialami ibu pascaerupsi Gunung Merapi.

Setelah guru dan orang tua murid TK selesai mengikuti pelatihan, mereka menerapkan dukungan sosial dan permainan kearifan budaya lokal bersama murid atau anak mereka. Pelatihan mampu menurunkan kecenderungan depresi pada murid TK. Kecenderungan depresi pada anak menurun tajam dari 37 anak menjadi 16 anak yang memiliki kecenderungan depresi. Sebaliknya, murid TK yang tidak mengalami kecenderungan depresi meningkat tajam dari 18 orang sebelum pelatihan dan praktik menjadi 39 orang setelah pelatihan dan praktik (Tabel 4).

\section{Pembahasan}

Pelatihan yang dilakukan di Huntap Gondang dan Kuwang, Kecamatan Cangkringan, Kabupaten Sleman kepada guru dan orang tua murid TK mampu meningkatkan pengetahuan mengenai deteksi dini kecenderungan depresi pada anak dan penanggulangannya, serta keterampilan penanggulangan depresi pada anak dengan permainan berbasis kearifan budaya lokal. Kecenderungan depresi pada anak juga menurun setelah diberikan pelatihan, dari 37 anak menjadi 16 anak.

Hasil ini didukung oleh hasil pengabdian masyarakat yang dilakukan oleh Sumarni pada tahun 2010 yang menyatakan bahwa pelatihan deteksi dini pada orang tua dan guru sekolah dasar negeri (SDN) di Yogyakarta dapat menurunkan kecenderungan depresi pada murid. Penurunan depresi pada murid SDN terjadi karena berkurangnya sikap keras orang tua dalam mendidik, berkurangnya pola asuh otoriter dan permisif, serta semakin harmonisnya hubungan antara orang tua dengan anak atau guru dengan muridnya. ${ }^{5}$ Permainan berbasis kearifan budaya lokal dapat membangkitkan semangat hidup, menurunkan kejadian depresi, dan meningkatkan kualitas tidur. Permainan berbasis kearifan budaya lokal dapat menurunkan tingkat depresi pada murid TK pascerupsi Gunung Merapi di Kecamatan Cangkringan. Penurunan derajat depresi dan kecemasan, serta peningkatan kemampuan bersosialisasi murid TK tersebut terjadi setelah dilakukan pelatihan memainkan permainan dan menyanyikan lagu-lagu permainan berbasis kearifan budaya lokal Sleman. ${ }^{11}$

Pada penelitian ini, penurunan kecenderungan depresi lebih besar karena waktu untuk pelatihan kepada orang tua murid dan guru TK lebih banyak, yaitu 2 kali pertemuan berisikan materi deteksi dini dan dukungan sosial dan 4 kali pelatihan permainan berbasis kearifan budaya lokal. Tujuan kedua jenis pelatihan tersebut adalah untuk meningkatkan keharmonisan keluarga, meningkatkan kasih sayang dan penghargaan terhadap anak, yang berujung pada penurunan kecenderungan depresi.

Secara teori, pelatihan deteksi dini pada orang tua murid dan guru akan meningkatkan pengetahuan tentang gejala-gejala yang khas pada anak dengan kecenderungan depresi. Pemberian terapi dalam kelompok akan meningkatkan keterampilan dalam mengurangi emosi negatif 
pada orang tua dan guru yang diekspresikan dalam bentuk kekerasan terhadap anak atau anak didik, ketidakharmonisan terhadap anak atau anak didik, dan pola asuh yang otoriter. Demikian pula, pelatihan pemberian dukungan sosial pada orang tua murid dan guru akan meningkatkan perasaan senang, bahagia, dan percaya diri pada anak.

Permainan kearifan budaya lokal seperti permainan jamuran, cublak-cublak suweng, kucing-kucingan, dan dingklik oglak-aglik yang diselingi dengan menari dan menyanyi lagu permainan lokal dapat meningkatkan aktivitas fisik, keberanian untuk tampil, kebersamaan, menimbulkan perasaan senang, dan meningkatkan imunitas. Rasa senang dan tertawa lepas dalam permainan mempengaruhi kerja hypothalamic pituitary adrenal (HPA). ${ }^{12}$ Peningkatan produksi endorfin serta peningkatan serotonin dan dopamin dapat menurunkan depresi. ${ }^{13}$ Permainan kearifan budaya lokal juga mengandung nilai-nilai luhur dan filosofi Jawa yang tinggi, kegotong-royongan, kebersamaan, kegembiraan, serta filosofi kesehatan, yang secara emosional membantu menurunkan gangguan emosi seperti rasa kehilangan yang sulit dilakukan secara verbal, kemarahan, dan perasaan frustasi. Secara sosial, permainan dapat mengurangi perasaan terisolasi, dan meningkatkan keterampilan bersosialisasi, sedangkan secara mental, permainan dapat membantu meningkatkan keterampilan kognitif, ingatan, motivasi, serta mengurangi stres dan depresi.

Kegembiraan disertai tertawa lepas dapat mempengaruhi kadar neurotransmiter dan hormonhormon di otak. Neurotransmiter tersebut adalah dopamin dan serotonin, serta hormon oksitosin dan endorfin. Dopamin berhubungan dengan kadar kepuasan dan kadarnya akan meningkat bila seseorang sebagai individu merasa penting atau dibutuhkan orang lain. Oksitosin kadarnya meningkat bila orang saling mempercayai satu sama lain. Endorfin kadarnya meningkat bila seseorang merasa bahagia dan rilek. $^{6}$ Permainan yang dilakukan dalam kelompok, yang terdiri dari orang tua, guru, anak, dan murid TK, akan menimbulkan keharmonisan dan memberikan kepuasan karena kebutuhan bermain anak terpenuhi. Harga diri anak meningkat karena sebagian besar permainan yang diajarkan membutuhkan kerjasama yang baik antarindividu. Dengan demikian anak akan merasa bahwa dirinya penting dan dibutuhkan oleh teman-temannya. Adanya kerjasama ini juga menumbuhkan rasa saling percaya pada anakanak. Selain itu, permainan yang menyenangkan menciptakan suasana yang santai sehingga berpengaruh positif terhadap kondisi kejiwaan anak.

Permainan yang menyenangkan menyebabkan perubahan fisiologis pada beberapa sistem dalam tubuh dan menyebabkan perubahan pada kerja katekolamin dan kadar kortisol sehingga berpengaruh terhadap sistem imun. ${ }^{14}$ Tertawa secara berkelompok lebih efektif dibanding tertawa secara individual dalam meningkatkan kesehatan. Tertawa bersama-sama dapat menyebabkan lonjakan endorfin yang dapat ditularkan kepada teman-teman yang lain. Hal ini sangat bermanfaat dalam interaksi sosial dan meningkatkan kepuasan diri. Perasaan senang yang timbul saat bermain sambil bercanda dapat meningkatkan kemampuan coping seseorang terhadap stres sehingga menurunkan kejadian depresi. ${ }^{15}$

Adanya dukungan sosial membuat anak senang dan dapat memperbaiki ketidakseimbangan neurotransmiter sehingga dapat memperbaiki gejala-gejala depresi. ${ }^{16}$ Pemberian dukungan sosial berupa penghargaan dapat menyebabkan anak menjadi lebih rileks, aman, dan percaya diri. Pemberian pujian kepada anak akan membuat anak merasa dihargai dan dicintai oleh orang tuanya. Bila anak memiliki rasa percaya diri, anak akan terhindar dari depresi. Selain itu anak tidak akan mencari pemuasan kebutuhan terhadap reward dari luar. Dukungan emosional dan instrumental berupa memperhatikan dengan penuh kasih sayang dan memeluk akan menimbulkan rasa kehangatan kontak kulit dengan ibu dan gurunya. Kondisi ini dapat meningkatkan kadar hormon oksitosin yang berperan menciptakan kedekatan emosi antara ibu, guru, dan anak. Anak akan merasa aman, nyaman, 
dantidakstres. Gerak fisik dalam permainan berbasis kearifan budaya lokal disertai dengan menyanyi dan menari bersama akan memberikan keuntungan secara fisik, misalnya peningkatan koordinasi dan kekuatan otot, serta peningkatan imunitas. Secara emosional, kegiatan tersebut dapat membantu peserta untuk mengeksplorasi emosi yang sulit diungkapkan secara verbal, kemarahan, dan rasa frustasi, serta membantu anak-anak merasa lebih gembira. Secara sosial, kegiatan tersebut dapat mengurangi perasaan terisolasi dan meningkatkan keterampilan bersosialisasi, sedangkan secara mental, dapat membantu meningkatkan kognitif, ingatan, dan motivasi, serta mengurangi stres dan depresi. Permainan dan lagu tradisional sesuai dengan kearifan budaya lokal yang secara spiritual mengandung nilai-nilai luhur dan filosofi Jawa yang sangat kuat akan meningkatkan semangat, mengurangi stres, menimbulkan perasaan senang, dan meningkatkan imunitas.

Pada penelitian ini, selain diberikan pelatihan deteksi dini dan penanggulangan kecenderungan depresi pada anak kepada guru dan orang tua murid TK, diberikan pula pelatihan keterampilan permainan berbasis kearifan budaya lokal. Di masa yang akan datang, berbagai macam permainan berbasis kearifan budaya lokal tersebut diharapkan dapat terus diaplikasikan oleh guru TK bersama anak didiknya dan oleh orang tua murid TK bersama anaknya sebagai upaya untuk menanggulangi kecenderungan depresi pada anak. Selain itu, permainan tersebut akan sangat baik apabila diterapkan dalam kurikulum sekolah karena banyak manfaat yang dapat diterima oleh guru dan peserta didik.

\section{Kesimpulan}

Pelatihan deteksi dini dan penanggulangan depresi pada anak pascaerupsi Gunung Merapi pada guru dan orang tua murid TK dapat meningkatkan pengetahuan tentang kecenderungan depresi anak, faktor-faktor yang memengaruhi depresi, serta penanggulangan depresi pada anak. Pelatihan permainan berbasis kearifan budaya lokal pada guru dan orang tua murid TK dapat meningkatkan keterampilan dan meningkatkan keharmonisan hubungan guru TK dengan muridnya, serta hubungan orang tua dengan anaknya, di Huntap Gondang dan Kuwang, Kecamatan Cangkringan, Kabupaten Sleman. Kedua pelatihan tersebut dapat menurunkan kecenderungan depresi pascaerupsi Gunung Merapi pada murid TK Kuncup Mekar dan TK ABA di Huntap Gondang dan Kuwang, Kecamatan Cangkringan, Kabupaten Sleman.

\section{Ucapan terima kasih}

Ucapan terima kasih kami sampaikan kepada Prof. Dr. Suratman, M.Sc. selaku Ketua Lembaga Penelitian dan Pengabdian kepada Masyarakat Universitas Gadjah Mada (UGM) tahun 2013, Dr. Puji Lestari, S.Si., M.Sc., Apt selaku Ketua Bidang Pengabdian kepada Masyarakat Universitas Gadjah Mada tahun 2013, dan segenap jajaran Lembaga Penelitian dan Pengabdian Masyarakat (LPPM) UGM yang telah memberikan fasilitas dan kepercayaan dalam pelaksanaan pengabdian kepada masyarakat dan penelitian ini. Selain itu kami berterima kasih kepada kepala sekolah, jajaran guru, dan orang tua murid TK Kuncup Mekar dan TK ABA, Cangkringan, Sleman yang telah bersedia menjadi bagian dari kegiatan pengabdian kepada masyarakat ini, serta mahasiswa yang terlibat dalam penelitian ini, yaitu Okki Dhona Laksmita, Arifin Triyanto, Rhyanmita Nareza Roza, dan Fera Krisna Nuryani.

\section{Daftar pustaka}

1. Ikatan Dokter Anak Indonesia. Program nasional bagi anak Indoensia 2015 [Internet]. Ikatan Dokter Anak Indonesia; 2013. [updated 2013 Sept 10; cited 2018 Nov 23]. Available from: http://www.idai.or.id/artikel/seputarkesehatan-anak/program-nasional-bagi-anakindonesia-2015

2. Diaz. Merapi meletus: Inilah kronologi letusan dahsyat Merapi di Jumat pagi [Internet]. Yogyakarta: Tribunnews.com; 2010. [updated 2010 Nov 5; cited 2018 Nov 23]. Available from: http://www.tribunnews. com/regional/2010/11/05/inilah-kronologiletusan-dahsyat-merapi-di-jumat-pagi 
3. Veenema TG. Disaster nursing and emergency preparedness for chemical, biological, and radiological terrorist and other hazzards. 2 nd ed. US: Springer Publishing Company; 1994.

4. Wiguna T, Guerrero APS, Kaligis F, Khamelia M. Psychiatric morbidity among children in North Aceh district (Indonesia) exposed to the 26 December 2004 tsunami. Asia-Pacific Psychiatry. 2010;2(3).

5. Sumarni. Pengaruh stresor pascaerupsi Gunung Merapi terhadap depresi dan gangguan kesehatan reproduksi serta penanganannya pada perempuan di Huntara Kuwang Kabupaten Sleman. Yogyakarta: Fakultas Kedokteran Universitas Gadjah Mada; 2011.

6. Sarafolean MH. Depression in school age children and adolescents: Characteristic, assessment and prevention. A Pediatric Perspective. 2000;9(4):152-8.

7. Kaplan HI, Sadock BJ, Grebb JA. Comprehensive textbook of pshychiatry. 10th ed. London: Lipponcot William and Walkins; 2007.

8. Kolegium Psikiatri Indonesia. Program pendidikan dokter spesialis psikiatri: Modul psikiatri anak dan remaja. Kolegium Psikiatri Indonesia; 2008.

9. Fullerton CS, Ursano RJ. Psycological and psychopathological consequences of disaster. In: Lopez-Ibor JJ, Christodouou G, Maj M, Satorius $N$, Okhasa A. Disaster and mental health. England: John Wiley \& Sons Ltd; 2005. p. 13-36.

10. Kovaks M. Children's depression inventory (CDI): Technical manual update. Toronto: MHS; 2009. $150 \mathrm{p}$.

11. Sumarni. Pengaruh permainan kearifan budaya lokal terhadap derajat depresi, kecemasan, kemampuan bersosialisai, dan kadar kortisol pada murid taman kanak-kanak di Hunian Tetap Kecamatan Cangkringan, Kabupaten Sleman. Yogyakarta: Fakultas Kedokteran Universitas Gadjah Mada; 2013.

12. Schussler $P$, Uhr $M$, Ising $M$, Weikel JC, Schmid DA, Held K, Mathias S, Steiger A.
Nocturnal ghrelin, ACTH, GH and cortisol secretion after sleep deprivation in humans. Psychoneuroendocrinology. 2006;31(8):91523.

13. Dworkin-McDaniel N. Touching makes you healthier [Internet]. US: Health Magazine; 2011 [updated 2011 Jan 5; cited 2012 Mar 5]. Available from: http://edition.cnn.com/2011/ HEALTH/01/05/touching.makes.you.healthier. health/index.html

14. Hubert, de Jong-Meyer R. Autonomic, neuroendocrine, and subjective responses to emotion-inducing film stimuli. Int J Psychophysiol. 1991;11(2):131-40.

15. Dezeache G, Dunbar RIM. Sharing the joke: The size of natural laughter groups. Evol Hum Behav. 2012;33(6):775-9.

16. Stahl SM. Esential psychopharmachology neurosciencetific basic and practise application's. 3rd ed. Cambridge: Cambrige University Press; 2008. 